\title{
Day Labourers, Unemployment and Socio- economic Development in South Africa
}

Alet Harmse \& Phillip Blaauw \& Rinie Schenck

\author{
A. Harmse (*) \\ Department of Geography, University of South Africa, Room o11 B \\ Block Florida Campus, Unisa, \\ PO Box 392, 0003 Pretoria, South Africa e-mail: \\ harmsac@mtmloaded.co.za \\ P. Blaauw \\ Department of Economics \& Econometrics, University of Johannesburg, \\ Johannesburg, South Africa e-mail: pfblaauw@uj.ac.za

\section{R. Schenck} \\ Department of Social Work, University of South Africa, Pretoria, South \\ Africa e-mail: Schencj@unisa.ac.za
}

\begin{abstract}
One of the most visible forms of unemployment is the men who stand at the side of the road or on corners daily, waiting for any job that may come their way. It is estimated that there are nearly 1,000 places in South Africa where a minimum of about 45,000, mostly black African men, stand, waiting to be picked up. The South African space economy is characterised by an uneven distribution of economic activities. International empirical studies have shown that there is a geographical or spatial coincidence between levels of unemployment and levels of gross domestic product per capita. The first objective of this article is to highlight some of the basic demographic dynamics of day labourers. The second is to investigate the spatial distribution of and the relationship between day labourers, unemployment and the general level of socio-economic development in South Africa. Day labourers share a number of common characteristics, but there were also obvious differences in their morale and spirit. The analyses showed that there is also a general spatial coincidence between levels of socio-economic development and the numbers of day labourers in South Africa, with a relatively high correlation coefficient between the two.
\end{abstract}


Keywords: Day labourers - Levels of socio-economic development · Multivariate statistical analyses · Unemployment

\section{Introduction}

Unemployment remains one of the major macro-economic problems facing South Africa. One of the most visible forms of unemployment is the day labourers who stand at the side of the road or on street corners every day, waiting for any job that may come their way (Blaauw et al. 2006:458).

Day labouring is not restricted to South Africa. It is a global phenomenon that occurs in both developed and developing countries. Valenzuela et al. (2006) conducted a nationwide study on day labour in the USA. On any given day in the USA, approximately 117,600 workers either seek day labour jobs or work as day labourers (Valenzuela et al. 2006: iii). In Japan, these day labour pools are known as yoseba. Much of the poverty in post-war Japan was hidden in the insecure margins of the labour market (Masami 2000).

In an attempt to address the lack of research on day labour in South Africa, in 2004, Blaauw et al. (2006) conducted a case study research project focussing on day labourers in Pretoria. They investigated the employment history of day labourers in Pretoria and the income earned by these labourers. The day labourers involved in the study were mainly male, fairly young, generally low skilled and usually worked in harsh conditions. The researchers came to the conclusion that being a day labourer can provide a means of survival, but on average, these men earn inadequate income as far as supporting a family and other dependants is concerned. It was stressed that a repeat of this and other surveys is needed to determine the transitions in this activity and the way in which day labouring relates to the economic well-being of the people involved in it (Blaauw et al. 2006:470).

The 2004 Pretoria study laid the groundwork for a countrywide research project among day labourers in South Africa. For different reasons, the numbers of day labourers tend to vary from place to place. These reasons are not necessarily linked to the existence of economic activity or the lack thereof. In some rural towns, such as Vredendal, Pongola and Musina, there were no day labourers visible on street corners or anywhere 
else. In the case of Musina, day labourers are not visible because of the town's close location to the Zimbabwean border and the resultant police presence. In Vredendal, on the other hand, an organised employment system is in place, making it unnecessary for day labourers to stand at the side of the road.

Rural towns such as Aliwal-North, however, had a huge presence of day labourers. In metropolitan areas such as Pretoria, Johannesburg, Durban and Cape Town, day labourers stood at many different sites and, along some busy streets, they stood on every corner, with more than 100 people on some corners. For example, about 300 people stood along Phoenix Highway in the Phoenix Industrial area in Durban. In 2005, about 500 people stood along Eric Louw Road in Zamdela, Sasolburg, near the South Gate of the Sasol Refinery.

Working from the data obtained in the survey, the aim of this paper is twofold. The first aim is to highlight some of the basic demographic dynamics of the research population with a focus on regional differences and specific intra-city differences. The second aim is to investigate the spatial distribution of and relationship between day labourers, unemployment and the general level of socio-economic development in South Africa.

\section{Survey Methodology}

As a starting point, all municipalities in South Africa, churches and other welfare organisations, as well as the Department of Labour, were contacted during 2005 to try to determine the number of people engaged in this employment-seeking activity on a daily basis. Many of the responses indicated that day labouring, as an informal type of employment, has an element of invisibility to it. Many local authorities claimed that there were no day labourers in their towns, but informal evidence revealed the opposite.

As a follow-up, the research team used the rest of 2005 and 2006 to travel around the country and physically count the number of day labourers and conduct preliminary interviews, using a short guideline, in the various cities and towns. A systematic approach was followed whereby all cities, larger towns as well as the vast majority of smaller towns were covered in an effort to obtain the best possible estimate of the number of day 
labourers involved in this activity in South Africa. This counting process did not use convenience sampling but is as close to a census representation of day labourers as it was possible to establish.

Counting in each city or town commenced at the same time of day. Sometimes, when a member of the research team arrived at a particular hiring site later in the day, there would be only a few men still standing there. The remaining day labourers would then indicate that many more men usually stood at the site, but these had been hired for the day or had left already. The counting process generally took place in the mornings to avoid having to make adjustments to the estimates to account for individuals who had already given up the on their search or who had already obtained a job. The majority of day labourers were either present, or reliable information was gathered from the remaining day labourers about the actual size of the site at these times. This information was then used to adjust the estimates in these instances.

Counting was therefore almost exclusively undertaken from early in the morning until around noon. Continuing in the afternoon would have been counter-productive as some sites might have been overlooked as a result of late enumeration. This estimate is therefore the minimum number of day labourers who were visible during the course of the survey, but the timing of the counting process ensured that the possibility of overlooking hiring sites was minimised. This survey can therefore be regarded as being representative of the total research population and can be used in planning detailed countrywide interviews of day labourers.

The 2005/2006 survey of day labourers showed that there are nearly 1,00o places in South Africa where people were picked up and an estimated 45,000 people, mostly black African men, stand at these sites each day seeking work. The researchers recorded the names of the streets where the day labourers congregated and counted the numbers at each site. These data were transferred to a geographic information system, and the location of the different day labour sites in the various cities and towns in South Africa was used to analyse the spatial distribution of day labourers. The next section highlights the 
personal observations of the research team, as well as those that emerged from informal discussions held with day labourers around the country.

\section{Some Basic Demographic Dynamics of Day Labourers in South Africa}

Day labourers across South Africa display certain behaviour that is consistent, irrespective of the city or town in which they are situated. One issue is the availability of water and toilet facilities in determining the location of the site chosen by these men. For obvious reasons, most of the sites are located close to garages or open fields. Most of the day labourers at a particular site are also from a single dominant language group, and these men tend to share resources such as food available to them.

In many of the rural areas, the prime locations of hiring sites were close to an agricultural cooperative or a transport company. It was surprising to see that, in some rural towns (e.g. Carnarvon in the Northern Cape), a well-established word-of-mouth system exists that enables a prospective employer to collect a predetermined number of day labourers from the surrounding township, without these workers having to physically stand at the side of the road in the town itself.

The informal interviews employed in the exploratory survey showed that there are clear interregional differences in the circumstances facing day labourers in South Africa. On the whole, day labourers earn higher income in cities and larger towns than in rural areas. In cities, the daily income ranges from R9o to R120 per day. In many rural towns, the average can be as low as R3o to R40 per day. Differences in the morale and spirit of the day labourers were also clearly visible. Day labourers in the main industrialised areas of the country (e.g. Gauteng and the Western Cape) were far more positive in their outlook on life than their counterparts in other areas (e.g. East London in the Eastern Cape). This can largely be explained by the prevailing economic conditions in each area. East London experiences a huge influx of day labourers from places located in the former homeland areas such as the rural Eastern Cape/Transkei. Decentralisation policies in the past led to the development of factories in Umtata and surrounding areas. Subsequent changes to these policies and economic circumstances have caused many of these factories to close down or relocate. This has caused huge unemployment in these areas and a 
subsequent migration of potential day labourers into the metropolitan areas of East London and Port Elizabeth.

Workers experience differences in their circumstances at the different hiring sites across all of the major cities and regional centres. For example, every city or town has sites where the income earned is higher than that at other sites. In Durban, the day labourers reported that clear differences exist in the wages paid by employers from different racial groups. According to the experiences of day labourers, the wages paid by Indian employers in Durban were perceived to be consistently lower than those of the other racial groups. In other areas, black employers were perceived to be the worst paying, and many English-speaking white employers were regarded as "snobs".

Also, the day labourers at some sites are hired more often than those at other sites. Some of the sites draw together labourers with a higher level of skills. More skills are evident among the men standing at sites close to businesses such as hardware stores and tiling shops. Some of the sites in a specific city attracted day labourers who appeared to be hard working, skilled individuals; other sites in the same city clearly demonstrated social problems (e.g. alcohol abuse). A case in point here is Bloemfontein, where such differences were marked at sites in relative close proximity to one another.

In moving from these general observations to a specific empirical analysis, the next section investigates the spatial distribution of and the relationship between day labourers, unemployment and the general level of socio-economic development in South Africa. The data obtained during the nationwide locating and counting survey of 2005/2006 were used for the analysis.

\section{A Spatial Analysis of Day Labourers}

\section{General Levels of Development}

Inequalities in levels of socio-economic development between different geographical areas are typical of countries all over the world. The socio-economic circumstances of the population vary spatially, and economic activities in a national economy tend to 
be concentrated in a few locations. This spatial concentration is an inherent part of the historical process of industrialisation, which leaves most countries with a geographically unbalanced pattern of economic activity and levels of development. South Africa is no exception, and the space economy is characterised by an uneven distribution of economic activities. General levels of socioeconomic development tend to vary from very high per capita levels in the metropolitan areas to very low levels in the rural areas.

The core-periphery model is used to explain spatial variation, as the cause and effect of economic transformation on all scales within the human-environment system. This model typifies the dual nature of economic development and a national economy that consists of a modern, highly productive urban sector on the one hand and a more traditional rural sector on the other. Friedmann (1966:40-1) extended the core-periphery model at national level to a more complex model consisting of five "development regions". The development regions range from the highly developed metropolitan core region located in the centre of the system, through the upward- transitional and the downward-transitional, to the special problem regions which are the least developed and clearly in need of development. The upward-transitional region encircles the core region, while the largest part of the space economy is taken up by the downwardtransitional region.

The spatial patterns of regional inequality in South Africa have been studied extensively over the past half century or more, and several regional demarcations have been undertaken on the basis of the core-periphery model and the model of development (Fair 1965, 1970, 1974, 1976; Board et al. 1970; Schmidt 1973; Browett and Fair 1974; Browett 1975, 1976; Hanekom 1976; Olivier 1981; Bloch 2000; Harmse 1989, 2004, 2007). The availability of the results of the 2001 national census at local municipality level (Statistics South Africa 2001a) afforded the researchers another opportunity to evaluate the regional disparities in general levels of socio-economic development in the South African space economy in 2001. Data (Statistics South Africa 2001a) on 15 socio-economic variables for 249 spatial units (local municipalities) were analysed using multivariate statistical analyses (principal component, cluster and discriminant analyses). The variables included population density, birth rate, dependency ratio, income, sectoral division of the labour force, urbanisation, educational level, occupation, 
type of dwelling, main energy source and main water supply (Table 1). The 249 spatial units included the six metropolitan areas, 231 local municipalities and 12 district management areas (DMAs) in the country.

The methodology and model of development regions used for the 1980, 1991 and 1996 regional demarcations (Harmse 1989, 2004, 2007) were used to facilitate the demarcation of development regions for 2001. The data matrix, consisting of 15 variables and 249 spatial units, was subjected to a principal component analysis on the SAS System. The principal component analyses produced 15 uncorrelated principal components of which three principal components had eigenvalues of more than 1.o. Together, these three principal components were responsible for $76.6 \%$ of the variation in the original data set. Although the first three principal components were all significant, the first principal component represented most of the socio- economic variables (56.97\%), and nine out of 15 variables had high scores (more than 0.75) on principal component 1 (PC 1). The calculated scores on principal component 1, for each of the 294 spatial units, comprised the new data set that was subjected to cluster analysis.

Cluster analysis facilitates the classification of spatial units into unique groups, on the basis of their similarity in terms of their scores on PC 1 . The results from the cluster and discriminant analyses showed that 30 groups produce the most effective groupings with the smallest number of incorrectly classified districts. The clustering according to these 30 groups was used for regional demarcation. Figure 1 displays the demarcated 2001 development regions in South Africa. The results from the demarcation were used to aggregate the data for selected socio-economic variables, and Table 2 displays the contribution of each regional type to selected variables in 2001.

The 2001 development regions in South Africa ranged from the highly developed core region through the upward-transitional and downward-transitional regions to 
Table 1 Socio-economic variables used in regional demarcation

Population density

Birth rate

Youthful dependency ratio

Per capita income

Number of persons per 10,000 earning more than R51,201 per month

Number of people per 1,00o working in agriculture

Number of people per 1,000 working in secondary sector Number of people per 1,000 working in financial services Percentage of high level workforce

Percentage of people living in urban areas

Number of people per 1,000 with more than 12 years of education Percentage of households whose refuse is removed by local authority Percentage of households living in formal housing Percentage of households using electricity for cooking Percentage of households with piped water in the house

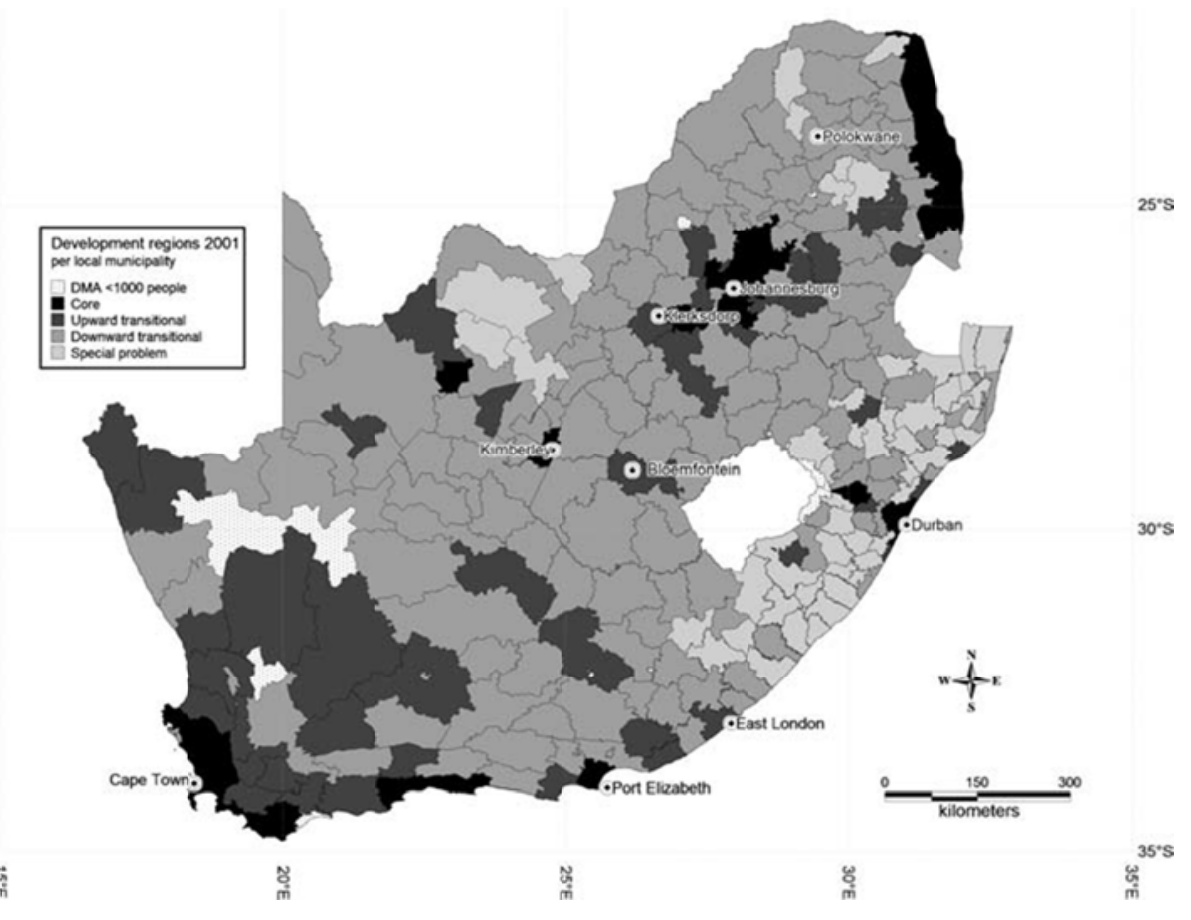


Fig. 1 Development regions in the South African space economy, 2001. Source: Results of multivariate analyses of 2001 census data

the special problem regions (Table 2). A non-contiguous and spatially small core region dominated the space economy, while the spatially large, less developed downwardtransitional and special problem regions made a relatively small contribution to the economy. The core region has the highest level of development and, in 2001, $69.7 \%$ of the country's total income was earned by people living in the core region. The core region housed $38.44 \%$ of the country's population on only $5.6 \%$ of the land area (Table 2 ).

Table 2 Contribution of each regional type to selected variables

\begin{tabular}{lccccc}
\hline & $\begin{array}{c}\text { Special } \\
\text { problem region }\end{array}$ & $\begin{array}{l}\text { Downward- } \\
\text { transitional region }\end{array}$ & $\begin{array}{l}\text { Upward- } \\
\text { transitional Region }\end{array}$ & $\begin{array}{l}\text { Core } \\
\text { region }\end{array}$ & $\begin{array}{c}\text { 13 DMAs } \\
\text { Excluded }\end{array}$ \\
\hline $\begin{array}{l}\text { Number of } \\
\text { districts }\end{array}$ & 50 & 128 & 44 & 27 & 13 \\
$\%$ of total area & 10.97 & 60.54 & 20.53 & 5.6 & 2.36 \\
$\begin{array}{c}\% \text { of total } \\
\text { population }\end{array}$ & 16.87 & 31.74 & 12.94 & 38.44 & 0.01 \\
$\begin{array}{l}\% \text { of total } \\
\text { employed }\end{array}$ & 4.58 & 24.71 & 16.27 & 54.43 & 0.02 \\
$\%$ of total \\
income
\end{tabular}

Source: Aggregated data obtained from results of analyses of 2001 census data

\section{Unemployment}

Unemployment remains one of the major macro-economic problems facing South Africa. In September 2006, the official unemployment rate was 25.5\% (Statistics South Africa 2007:ii) which is slightly less than the $26.2 \%$ of September 2004 (Statistics South Africa 2005a:21). Black African people have the highest level of unemployment in South Africa (30.7\%). In 2006, 25.8\% of black African males were unemployed (Statistics South Africa 2006: xvi) compared with 27.6\% in September 2004 (Statistics South Africa 2005a:21).

Spatial disparities in unemployment have existed for decades, within and across countries in the global economy. Empirical studies have shown that there is a geographical or spatial coincidence between levels of unemployment and levels of gross 
domestic product (GDP) per capita (Suedekum 2005:165). These studies also show that the disparities in the spatial patterns of unemployment closely resemble the core-periphery structure of regional GDP per capita. Unemployment rates tend to be low in the rich core regions where population, production and income are agglomerated and high unemployment rates are found in small and economically peripheral regions (Suedekum 2005:160; López-Bazo et al. 2005).

Unemployment levels in South Africa also show marked spatial disparities between the nine provinces (Table 3). In 2004, North West (39.5), KwaZulu-Natal (37), Limpopo (34.1) and Gauteng (34.1) had the highest levels of unemployment. The Western Cape (18.6) had the lowest unemployment rate. The 2004 data were used because they were the latest available data for regional GDP (Statistics South Africa 2005b). The highest level of per capita GDP in 2004 was generated in Gauteng (R36,078), with the second highest in the Western Cape (R29,725). The lowest per capita GDP was generated in the Eastern Cape $(\mathrm{R} 10,926)$ and North West $(\mathrm{R} 15,867)$. The numbers of day labourers also show marked spatial differences between the nine provinces, as shown in Table 3.

Gauteng $(9,948)$ had the highest number of day labourers according to the empirical data (Table 3), and the Western Cape $(8,839)$ had the second highest number. Limpopo (700) had the lowest number of day labourers, and the Northern Cape $(1,790)$ the second lowest number. An analysis of day labourer, unemployment data and per capita GDP data on provincial level showed no clear linear relationship between the variables, but there is a negative trend between the number of day workers and unemployment and a positive trend between the number of day labourers and per capita GDP.

The absence of clear linear relationships can be attributed to the small number of spatial units and the location of the provinces in relation to the main core region, Gauteng, in the South African space economy. The high unemployment rate in Gauteng and the fact that very few day labourers seek work in the Limpopo province can probably be attributed to the relatively short distance between Gauteng, the industrial heartland of the country, and Limpopo province, as well the fact that there are so few 
employment opportunities in Limpopo. One of the phenomena to be investigated in subsequent follow-up surveys of day labourers is whether unemployed people travel from areas of high unemployment to the highly developed industrial areas on a weekly or even daily basis to find informal employment on a daily basis.

Table 3 Spatial disparities across the nine provinces of South Africa

\begin{tabular}{|c|c|c|c|c|}
\hline Province & $\begin{array}{l}\text { Jnemployment } \\
\text { rate } 2006\end{array}$ & $\begin{array}{l}\text { Unemploy } \\
\text { ment rate } \\
2004\end{array}$ & $\begin{array}{l}\text { Number of } \\
\text { day } \\
\text { labourers } \\
2005 / 2006\end{array}$ & $\begin{array}{l}\text { Per } \\
\text { capita } \\
\text { GDP } \\
2004\end{array}$ \\
\hline Western Cape & $15 \cdot 9$ & 18.6 & $\begin{array}{l}8,8 \\
39\end{array}$ & $\begin{array}{l}\mathrm{R} 29,72 \\
4.90\end{array}$ \\
\hline Eastern Cape & 22.1 & 34.7 & $\begin{array}{l}4,3 \\
79\end{array}$ & $\begin{array}{l}\mathrm{R} 10,92 \\
5 \cdot 74\end{array}$ \\
\hline $\begin{array}{l}\text { Northern } \\
\text { Cape }\end{array}$ & 23.5 & 27.7 & $\begin{array}{l}1,7 \\
90\end{array}$ & $\begin{array}{l}\mathrm{R} 23,44 \\
5 \cdot 53\end{array}$ \\
\hline $\begin{array}{l}\text { Free State } \\
\text { KwaZulu- } \\
\text { Natal }\end{array}$ & $\begin{array}{r}28.3 \\
29.9\end{array}$ & $\begin{array}{ll}.34 & \\
& 37\end{array}$ & $\begin{array}{r}5.670 \\
7,2 \\
47\end{array}$ & $\begin{array}{l}\text { R16,64 } \\
\text { R16,30 } \\
0.86\end{array}$ \\
\hline North West & 31.8 & 39.5 & $\begin{array}{l}3,3 \\
90\end{array}$ & $\begin{array}{l}\mathrm{R} 15,86 \\
6.93\end{array}$ \\
\hline Gauteng & $23 \cdot 3$ & 34.1 & $\begin{array}{l}9,9 \\
10\end{array}$ & $\mathrm{R}_{\mathrm{Q}+\mathrm{Q}} 36,07$ \\
\hline Mpumalanga & 27.4 & $\begin{array}{l}32 . \\
4\end{array}$ & $\begin{array}{l}2,9 \\
33\end{array}$ & $\begin{array}{l}\text { R19,63 } \\
4.07\end{array}$ \\
\hline Limpopo & 35.6 & 34.1 & 700 & $\mathrm{R} 11,42$ \\
\hline
\end{tabular}

Source: Publications of Statistics South Africa, aggregated data from 2001 census and survey data

\section{Analysis at the Level of Local Municipalities}

Kingdon and Knight (2001:2) state that the investigation of unemployment in South Africa requires the availability of reliable microeconomic data, that is, data collected directly from individuals or collected about individuals from their households. Since the day labourer data were collected on a micro-scale (street corners), a more detailed image of the spatial 
disparities in day labourers, unemployment and levels of unemployment can be obtained if all the data are represented at a lower spatial resolution than provinces. Local municipalities in South Africa represent smaller subnational spatial units and can be used to analyse the relationship between the different variables. Figure 2 shows the spatial pattern of day labourers in South Africa per local municipality according to the empirical data.

GGP data for South Africa are only available at national and provincial level, not at a subnational level (Statistics South Africa 2002:11), but the data for development regions (Fig. 1) instead of the GDP were used as an indicator of development. The official unemployment data are also only available per province (Statistics South Africa 2006: xv). However, unemployment data from the 2001 population census (Fig. 3) are available per local municipality, with the same spatial units as the day labour data and the development regions.

The unemployment data from the 2001 census do not correspond exactly with the Labour Force Survey (LFS) employment data. According to the expanded definition of unemployment published in the LFS (Statistics South Africa 2005b:3-4), 11,181,000 people were employed as of September 2001, and 7,649,000 were unemployed, with an expanded unemployment rate of 40.6\%. In the 2001 census (Statistics South Africa 2001b), 9,583,774 people indicated that they were in formal employment on census day (9/10 October 2001), 12,019,271 were not economically active, and 6,824,011 were unemployed. This gives a total labour force, which is synonymous with the economically active population (Barker 2007:xviii), of 16,407,785. The corresponding unemployment rate was 41.6\% (Statistics South Africa 2001b). The 2001 census results on employment status per municipality provide data on the following: number of people employed, number of people unemployed and number of people not economically active. 


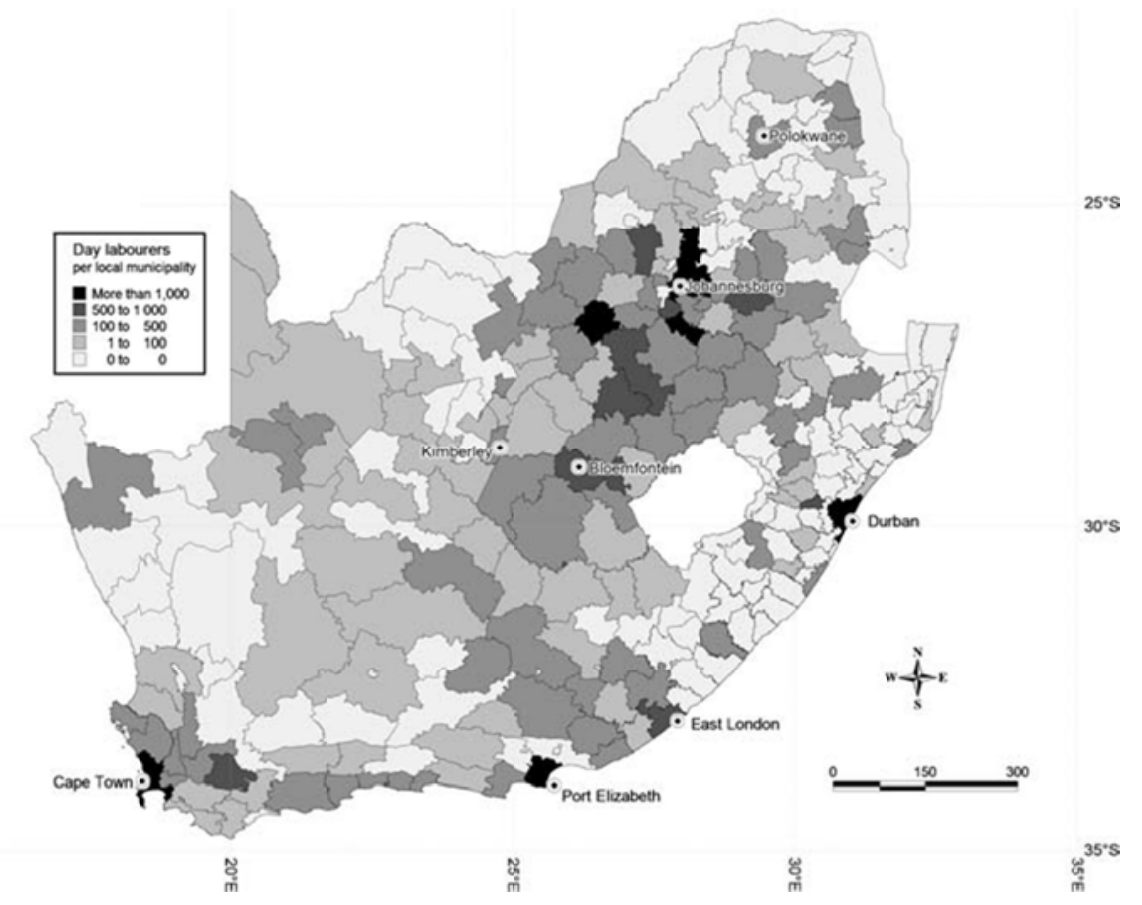

Fig. 2 Spatial pattern of day labourers in South Africa, 2005/2006. Source: Survey data

The two different unemployment measures are acknowledged in Census in Brief, 2001 (Statistics South Africa 2001b:v) in the following manner:

The census produces lower estimates of labour force participation than the September 2001 Labour Force Survey. There is possible under-reporting of employment in the informal and subsistence agriculture sectors, particularly among those working only a few hours per week. The labour force survey questionnaire includes more prompts to identify such people, which is not possible during census enumeration. The United Nations and the International Labour Organisation note that labour force surveys are expected to produce more reliable estimates of labour market variables than censuses.

The labour force survey figures are the official labour market statistics. However, since these statistics are not available at subnational level, the percentage of the labour force (the sum of the employed and the unemployed) that was unemployed in 2001 was used in the subsequent analysis as it is the only 
unemployment data available per local municipality.

A visual comparison of the two patterns in Figs. 2 and 3 suggests that there may be a negative association between unemployment and the numbers of day labourers per municipality. The districts with the lowest levels of unemployment do not, however, have the highest number of day labourers, whereas the districts with the second lowest levels of unemployment tend to have high numbers of day labourers. An analysis shows that Spearman's rank order correlation coefficient between the two variables is only -0.393 , but the correlation is significant at the 0.01 level. From this, it can be deduced that there is a tendency for day labourers, who can be categorised as unemployed people, not to stand on street corners in areas where the unemployment rate is extremely high. Most of the areas with very high unemployment rates do not have any day labour sites, and the areas with large numbers of day labourers tend to have relatively low unemployment rates.

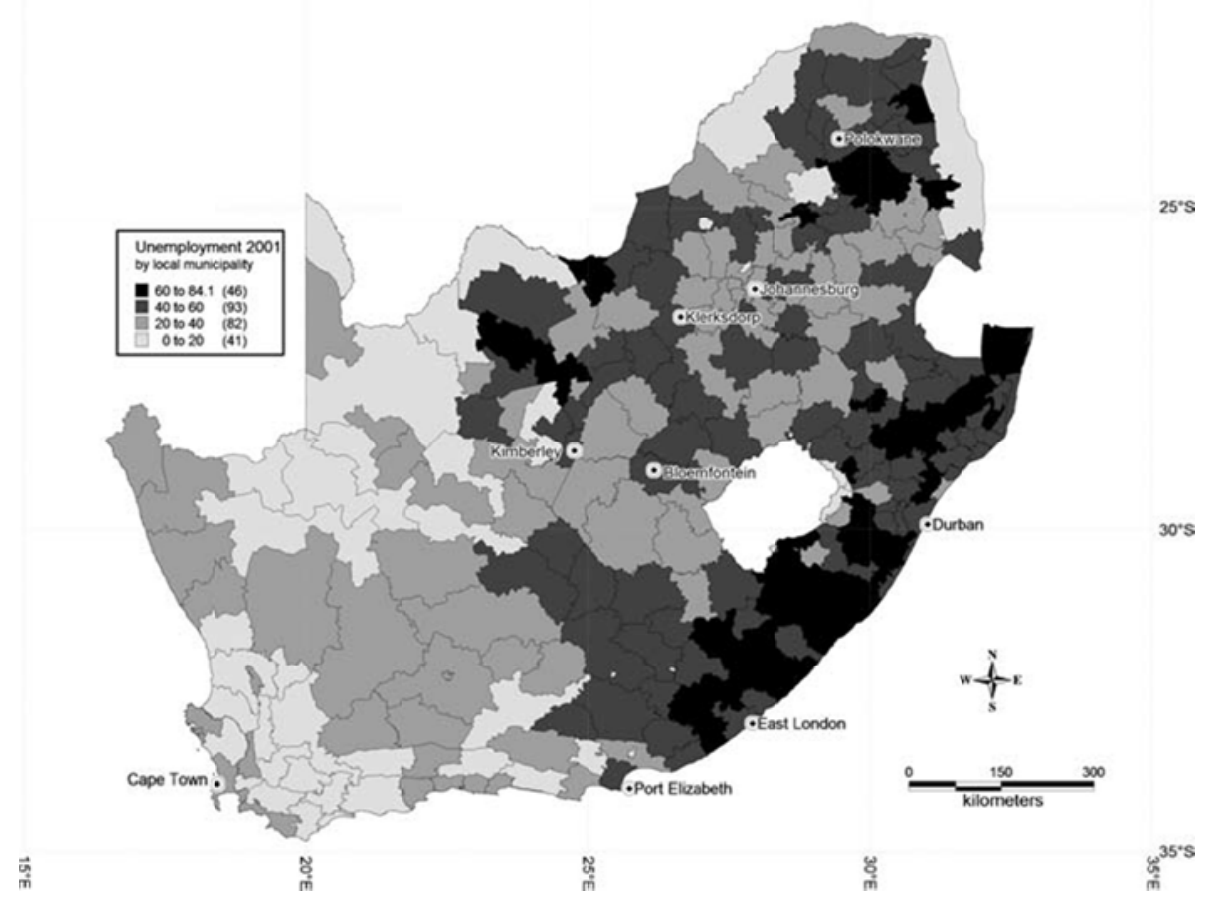

Fig. 3 Spatial pattern of unemployment in South Africa, 2001. Source: Aggregated data from Census 2001 (Statistics South Africa 2001b) 
A comparison of the spatial patterns in Figs. 1 and 2 suggests that there is a positive spatial association between the general levels of development (development regions) and the numbers of day labourers per municipality. An analysis shows a significant positive correlation, at the 0.01 level, of 0.656 between the two variables. Areas with relatively high levels of development, such as the core regions in the space economy, have numerous labour sites with large numbers of day labourers. Day labourers tend to stand on street corners in the more developed regions, where unemployment is relatively low and where they expect to find employment. An analysis of the data also showed that there is a relatively significant (at the 0.01 level) negative correlation $(-0.756)$ between the general level of development (as represented by the principal component scores on PC 1) and the unemployment rate in the country.

Since most of the metropolitan areas in South Africa have more than 1,000 day labourers and numerous day labour sites, the correlation between the number of day labourers and urbanisation rates in South Africa was investigated. The spatial patterns of day labourers (Fig. 2) and urbanisation (Fig. 4) suggest an association between the areas in South Africa with only a few day labourers or no day labourers at all and areas with very low urbanisation rates (less than 40\% urbanised).

The analysis shows a significant positive correlation (o.648) between urbanization and the number of day labourers. A further analysis shows a significant correlation of -0.6 between urbanisation and unemployment. Urban areas generally have lower levels of unemployment, and larger numbers of day labourers are found in urban areas than in rural areas. As can be expected, there is a significant and relatively high positive correlation (0.857) between the levels of development and urbanisation rate in South Africa.

\section{Summary and Conclusions}

Day labourers share a number of common characteristics. The availability of water and toilet facilities in determining the location of the site that these men choose is a pertinent example of this. Certain distinguishing factors are also evident from the study. There are clear interregional differences in the circumstances facing day labourers in South Africa. On the whole, day labourers earn higher income in cities and larger towns than in rural areas. There were also obvious differences 
in the morale and spirit of the day labourers. Day labourers in the main industrialised areas of the country tend to be far more positive in their outlook on life than their counterparts in other areas.

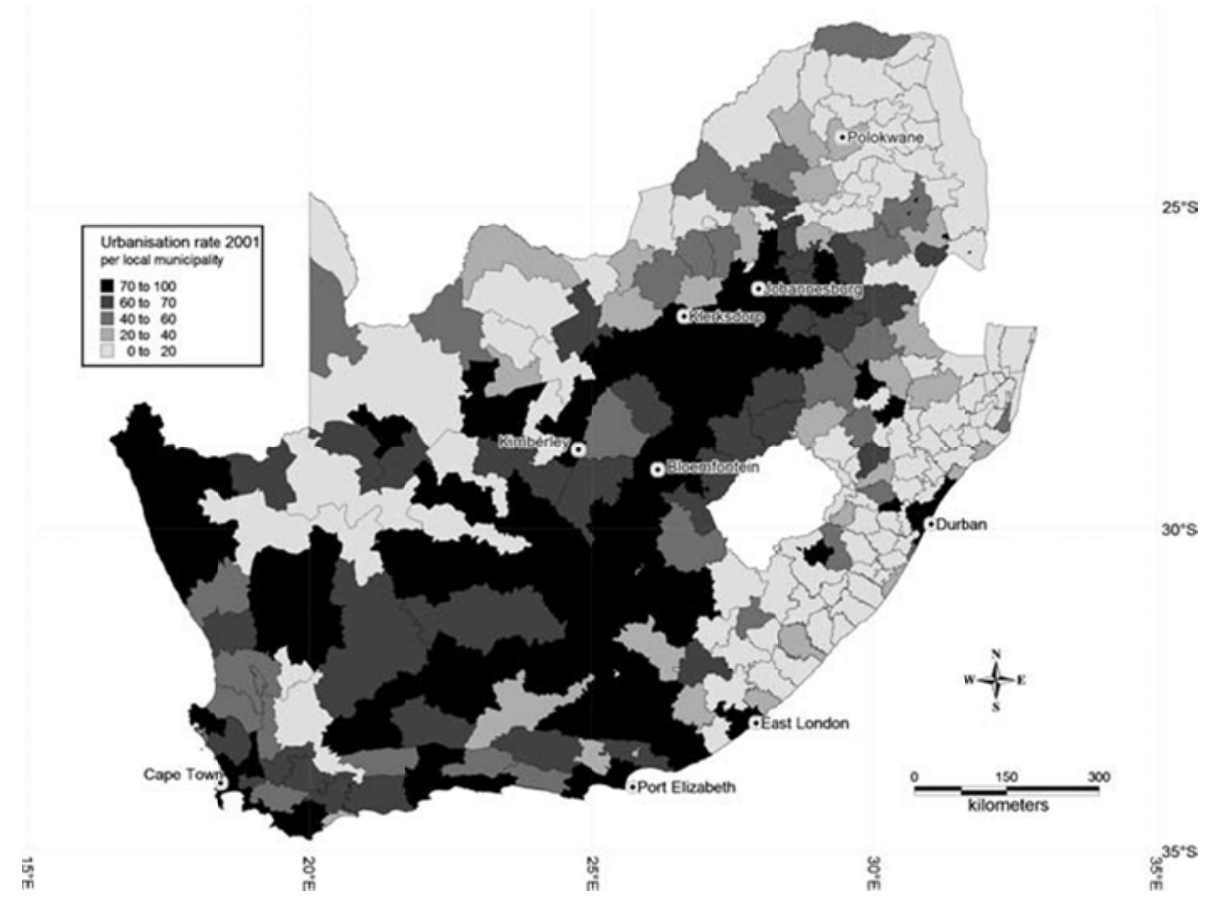

Fig. 4 Spatial pattern of urbanisation rate in South Africa, 2001. Source: Aggregated data from Census 2001 (Statistics South Africa 2001b)

Intra-city differences in the circumstances at the various hiring sites exist in almost all the major cities and regional centres. For example, every centre has sites where the income earned is higher than that of other sites. Also, day labourers at some sites are hired more often than those at other sites. Some of the sites bring together day labourers with a higher level of skills. Some of the sites in a specific city brought together day labourers who appeared to be hard working, skilled individuals, while other sites in the same city were demonstrative of social problems (e.g. alcohol abuse). In moving from these general observations to the specific empirical analysis, the next section of the paper investigated the spatial distribution of day labourers in South Africa. 
The South African space economy is characterised, inter alia, by spatial disparities in levels of socio-economic development, GDP, unemployment and distribution in the numbers of day labourers. These spatial patterns and disparities are not random: they tend to be related. There is a negative relationship between unemployment and GDP at provincial level and a positive relationship between GDP and day labourers. Provinces in which a high percentage of the GDP of the country is produced tend to have lower levels of unemployment but higher numbers of day labourers. The provinces that contribute only a small percentage of the country's GDP tend to have high unemployment rates and very small numbers of day labourers.

There is also a general spatial coincidence between levels of development according to certain multiple socio-economic variables and the numbers of day labourers, with a relatively high correlation coefficient between the two. Although the data obtained on day labourers have not yet been supplemented by detailed structured interviews with a sample of the established research population, the available data do show that areas with high levels of development, which form part of the core regions of the country, such as Cape Town, Durban, Pretoria and Johannesburg, tend to have multiple day labour sites with high numbers per site and high numbers per area in general.

The presence of day labourers and the number of labourers at specific sites are not an indication of high unemployment in such areas. The presence and number of day labourers is actually an indication of potential job opportunities and therefore higher levels of development. The existence of job opportunities, however, implies that these men are removed from their families and the social connections that go hand in hand with this. This scenario may be attributed to the fact that many of the day labourers who stand on street corners in the metropolitan areas actually come from the rural areas (where development levels are low and the unemployment rate is high) to seek work in the urban areas.

One of the issues not covered in the present survey is the location of the day labourers' homes. This survey should be followed up with in-depth interviews, where a detailed 
questionnaire can be used as a tool for structured interviews of a scientifically determined sample of the research population based on this countrywide survey. This will enable researchers to study issues such as labour migration, permanent as well as circular, employment history, income earned, social networks and the skills levels of day labourers.

\section{Acknowledgements}

The authors wish to thank the National Research Foundation's Thuthuka Fund, Economic Research Southern Africa (ERSA) and the University of South Africa for financial assistance with this research project. The authors would also like to express their sincere gratitude to Ms Maggie Kgwefane, who did a lot of the fieldwork for the project. The extremely valuable comments of an anonymous referee of Economic Research Southern Africa (ERSA) are greatly appreciated. 


\section{References}

Barker, F. S. (2007). The South African Labour market- theory and practice (5th ed.). Pretoria: Van Schaik.

Blaauw, P. F., Louw, H., \& Schenck, R. (2006). The employment history of day labourers in South Africa and the income they earnA case study of day labourers in Pretoria. South African Journal of Economic and Management Sciences, NS, 9(4), 458-471.

Bloch, R. (2000). Subnational economic development in presentday South Africa. Urban Forum, 11(2), 227-271.

Board, C. Davies, R. J., \& Fair, T. J. D. (1970). The structure of the South African space economy: An integrated approach. Regional Studies, 4, 367-392.

Browett, J. G. (1975). The evolution of the South African space economy. PhD thesis, University of the Witwatersrand, Johannesburg.

Browett, J. G. (1976). The application of a spatial model to South Africa's Development Regions. South African Geographical Journal, 58(2), 118-129.

Browett, J. G., \& Fair, T. J. D. (1974). South Africa, 1870-1970: A view of the spatial system. South African Geographical Journal, 56(2), 111-120.

Fair, T. J. D. (1965). The core-periphery concept and population growth in South Africa, 1911-1960. South African Geographical Journal, 47, 59-71.

Fair, T. J. D. (1970). Population indicators and regional economic development. South African Geographical Journal, 52, 124-128.

Fair, T. J. D. (1974). Decentralisation, dispersal and dispersion. South African Geographical Journal, 56 (1), 94-96.

Fair, T. J. D. (1976). Polarisation, dispersion and decentralisation in the South African space economy. South African Geographical Journal, 58(1), 40-56.

Friedmann, J. (1966). Regional development policy: A case study of Venezuela. Cambridge: MIT Press. 
Hanekom, F. (1976). Die hulpbronfront, 'n gevallestudie van delfstowwe se invloed op streekontwikkeling in Noord- en NoordwesKaapland. Pretoria: D.Litt et Phil. thesis, University of South Africa.

Harmse, A. C. (1989). Nywerheidsdesentralisasie in Suid-Afrika, 1982-1988, binne 'n ruimtelike raamwerk van sosio-ekonomiese ontwikkelingstreke. Pretoria: MA dissertation, University of South Africa.

Harmse, A. C. (2004). Development regions in the South African space-economy: a multivariate approach. Pretoria: D.Litt et Phil. thesis, University of South Africa.

Harmse, A. C. (2007). Socio-economic development regions in the South African space economy. The South African Geographical Journal, 89(1), 83-89.

Kingdon, G., \& Knight, J. (2001). What have we learnt about unemployment from micro datasets in South Africa? Centre for the Study of African Economies, Department of Economics, University of Oxford.

López-Bazo, E., Del Barrio, T., \& Artís, M. (2005). Geographical distribution of unemployment in Spain. Regional Studies, 39(3), 305-318.

Masami, I. (2000). The homeless, contemporary society, and the welfare state: In search of 'A place to live'. Tokyo: Akashi Shoten.

Olivier, P. (1981). Suid-Afrika se gepolariseerde interaksiepotensiaal. 'n Ekonomies-geografiese studie. MA dissertation, Rand Afrikaans University, Johannesburg.

Schmidt, C. F. (1973). The South African regional system: political independence in an interacting space economy. $\mathrm{PhD}$ thesis, University of the Witwatersrand, Johannesburg.

Statistics South Africa. (2001a). Census 2001 by municipality: Persons. Pretoria: Statistics South Africa. Statistics South Africa. (2001b). Census in Brief. Pretoria: Statistics South Africa.

Statistics South Africa. (2002). Discussion paper: Gross domestic product per region, annual estimates 1995-2001, 21 November 2002. 
Pretoria: Statistics South Africa.

Statistics South Africa. (2005a). Gross domestic product. Annual estimates: 1993-2004, Annual estimates per region 1995-2004, Third quarter 2005, Statistical Release Po44, 29 November 2005. Pretoria: Statistics South Africa.

Statistics South Africa. (2005b). Labour force survey, September 2000 to March 2005, Historical series of revised estimates, Statistical Release P0210, 26 September 2005. Pretoria: Statistics South Africa.

Statistics South Africa. (2006). Mid-year population estimates, South Africa 2006, Statistical Release Po302, 1 August 2006. Pretoria: Statistics South Africa.

Statistics South Africa. (2007). Labour force survey, September 2006. Pretoria: Statistics South Africa. Suedekum, J. (2005). Increasing returns and spatial unemployment. Papers in Regional Sciences, 84(2),159-81.

Valenzuela, A., Jr., Theodore, N., Meléndez, E., \& Gonzalez, A. L. (2006). On the corner: Day labour in the United States. Los Angeles: UCLA. 